Howe, C. (2014). Sexual adjudications and queer transpositions. Journal of Language and Sexuality, 3(1), 136-155. http://doi.org/10.1075/j1s.3.1.07how

\title{
Sexual adjudications and queer transpositions
}

\author{
Cymene Howe \\ Rice University, Houston, USA
}

Each of the articles included in this special issue of the Journal of Language and Sexuality asks us to imagine queer im/migration, asylum and sexual citizenship in multiple dimensions and to probe the discursive operations that establish the parameters of sexual subjectivity. This review article argues that these processes are illustrative of "sexual adjudication:" the discursive coordinates, legal logics and linguistic sensibilities that produce the category of the sexual migrant, the sexual refugee and the sexual asylum seeker. The discussions featured here engage questions of how sexual epistemics work in both sending and receiving countries, as well as the role of borders in constituting narratives of sexual subjectivity. In addition to analyzing the theoretical overlaps and reciprocal conversations between the articles included in the special issue, this essay provides a historical, comparative context by situating these discussions within larger theoretical and terminological questions regarding queer im/migration, asylum and subjectivity.

Keywords: sexuality, discourse, law, asylum, immigration, LGBTQ, subjectivity, epistemics, adjudication

\section{Introduction}

Media outlets and the trending journalistic topics they cover may not be indicative of deep cultural preoccupations, but they do represent nodal moments in public consciousness. They manifest a certain brand of fascination, even if it is fleeting. From 2009 to 2011, a handful of stories detailing sexual asylum appeared in the United States media. One series of stories 
documented the case of a heterosexual couple in Washington State who were illegally utilizing and profiting from the sexual asylum provision guaranteed by the U.S. government. ${ }^{1}$ The couple was discovered selling coaching sessions to undocumented immigrants, instructing them how to pass as gay in order to receive asylum protection in the United States. On the other side of the country, The New York Times turned attention [End Page 136] to an unspoken dynamic in asylum courtrooms where "socially visible" sexual minorities applying for asylum were being privileged over those who were less obviously gay. ${ }^{2}$ According to reports, men who appeared flamboyant and feminine were granted sexual asylum more often than those applicants who were less gender transgressive. The scheme devised by the Washington couple and the accusations of judicial favoritism reflect more than just a nefarious tale of sexual asylum sold for personal profit or recapitulated stereotypes about effeminate men and queer subjectivity. They signal, rather, the fragilities of sexuality when it is put on trial. As Judith Butler (2004: 32) has written, it is these sorts of moments when decisions are made about "which lives are worthy of protection" and the reverse: those that are not. In this article I suggest that what is at stake here is more than which lives deserve protection, but why and how they are made worthy of protection. This process, that I call "sexual adjudication," determines the legal logics and informs the linguistic sensibilities that produce the category of the sexual migrant, the sexual refugee and the sexual asylum seeker, helping to define their precarious citizenship.

Each of the articles in this special issue have engaged questions of sexual epistemics as well as the role of borders in constituting sexual subjectivity. The border in these cases both marks the boundaries of nation states and additionally, delineates intersubjective crossings. These dual crossings and codifications are evidence of queer transpositions; they are exercises of moving in space and time while also mobilizing one's subjective sensibility across particular registers of language and law. Such transpositions include recognizing one's self as a subject of gendered or sexual persecution, substantiating one's gay credentials and credulity, and narrativizing one's "own story" of sexual selfhood. As we have learned in each of the articles included here, these unique spaces of sexual and legal discourse create new avenues of both risk and opportunity for migrants who do not subscribe to the heteronorm. Each of the articles in this collection extend our understanding of queer migration, movement and the precarious status of being "legal" or not. My objective in this reflective essay is to bring together several of the discursive thematics and lines of inquiry that emerge in this special issue of the Journal of Language and Sexuality. The articles here ask how it is, specifically, that we imagine queer $\mathrm{im} /$ migration, asylum and sexual citizenship in its multiple dimensions, material, theoretical and linguistic. The discursive operations that seek to ascertain, "credulity" and "cause," for example, aim to establish particular parameters of sexual subjectivity. But they are also evidence of how legal sanctions become formed and formulated over time. These are clearly iterative processes to define and legally codify "the" sexual subject. In addition to considering the theoretical overlaps and reciprocal conversations that emerge here, I propose a set of historical signposts regarding immigration and sexuality as well as a broader context in [End Page 137] which to situate these discussions of language within queer migration, asylum and the constitution of subjectivity.

The pragmatics of policy and questions of social justice have compelled much of the scholarly work on queer migration in the humanistically oriented social sciences. Queer migrants often challenge tidy tales of assimilation that frequently make up the popular imaginaire of migratory journeys to the global north. As one of Martin Manalansan's (2003: 146) interlocutors put it, for example, "[w]e know all too well that there are very few places where people like us 
can really feel at home." Eithne Luibhéid (2002) describes a similar dynamic when she writes that LGBTQ im/migrants have been victims of a particularly profound "history of exclusion." Queer migrants, instead, experience "restructured" inequalities that work to undo a linear model of migration as a movement begun in repression and ending in liberation (Manalansan 2003: 13). Queer asylum seekers may utilize, reproduce and recapitulate sexual identity categories in their claims - enumerating for example, the ways in which they are marked and therefore vulnerable as lesbian or gay persons. However, we have come to see that queer migrants are also, at times, "impossible subjects" (Gopinath 2005). They extend, expand and challenge an easily assimilable sexual subject and category of personhood. Therefore, in order to critically engage with the discursive ways in which sexuality is conditioned by sexual migration, asylum and queer translocation, we require a sustained focus on the ways in which these sexual subjectivities become comprehensible, narrativized and legible through adjudicational practices in courtrooms and across borders.

\section{Sexual refuge, sexual revelation}

In each of the articles in this special issue, we find refusals to confer strict identitarian categories to migrants, transmigrants or asylum seekers. As they cross nation state borders, individuals' narratives and experiences embody various transpositions. Sexual migrants, queer refugees and asylum seekers may very quickly go from living in a context where they have been expected to defer, cover or reject their sexual selves, to, conversely, inhabiting a juridical field demanding that they compress their LGBT-Queerness into a legible, visible and packaged form. Moreover they are expected to place this identity, this sexual self — specifically a persecuted sexual self above all else. As David Murray shows in this special issue, it is often in quasi-judicial arenas that two poles of credibility are developed and questioned. As Murray puts it, "proving credible sexual or gendered orientation and proving credible persecution based on membership in this social group become deeply entangled in sexual identity terminologies with preexisting sociocultural determinate concepts." By centering close attention on the [End Page 138] discursive contours of sexual orientation refugee cases, Murray illustrates how the linguistic strategies used by adjudicators are mediated by training documents and guidelines. The credibility of claimants is determined by a series of bureaucratic truth claims. Murray's ethnographic and theoretical perspective provides an important vantage, demonstrating how it is that particular sexual epistemes become crafted through the asylum process for both claimants and their professionalized interlocutors. He asks how adjudicators determine facets of sexual credibility, and upon which sensorial and empathic criteria IRB (Immigration and Refuge Board) members predicate their decisions. Detailing these discursive exercises, as well as the construction of sexual credibility, Murray's article surfaces how refugees and attorneys, support groups and the IRB itself, both reproduce and challenge homonormative categories.

There are many expectations around what is dubbed "credibility." Murray centers attention on how IRB members cognitively and affectively engage the contingencies of the Canadian sexual asylum system. He details how this knowledge can be implemented to successfully navigate the complexity of the system, often at the price of having to define claimants in very essentialized terms (Murray 2012). The ability to be, or perhaps better said, appear, credible is a carefully managed process. It is similar, in form and substance to the process that Elizabeth Povinelli (2004) has described in regards to multiculturalist narratives. 
Crucial to the substantiation of one's credibility is being "discoverable." Credibility is constituted by the ability to be "recognized" (Povinelli 2004) or "legible" as a sexual subject (Howe 2009). Through this process we are reminded of a central epistemological condition - what Eve Sedgwick (1990) so famously inscribed at the center of western culture - the closet and its mirror. In each of Murray's cases the virtual closet gets rendered, reified and repeated. Juridical subjects must become sexual subjects and, moreover, transparent sexual subjects whose interiority can be clearly read by those adjudicating the case. Asylum applicants effectively find themselves the objects of a legal voyeurism. Claimants enter into the legal process in what Claude Lévi-Strauss would have called a "raw" condition, to then be "cooked" into a proper (that is credible) sexual self. This carefully crafted portrait is a live performance of putatively authentic gay/lesbian/trans/queer-ness, as claimants face their judge and as Board members react and adjudicate. But it is also a documentary performance: a series of manuscripts, reports and training documents that detail, to the letter, how to legitimate sexual subjectivity. There is an ontological exercise here that illustrates the fetish of both the embodied applicant and the power of the scripted file.

The category of the refugee and the sexual asylum seeker are each epistemic objects under construction (Malkki 1995), the limits of which are tested and prodded, often by agents of the state. Sexual asylum seekers are, in these accounts, [End Page 139] undergoing many of the same processes that have tested the intelligibility of gay and lesbian subjectivity. As queer theory and lesbian and gay studies over the past two decades have shown, LGBTQ identities have been appropriated and reformulated in different social contexts around the world (Boellstorff 2003, Howe 2013, Leap \& Boellstorff 2003). In part because of the massive increases in movement that globalization has rendered, sexual categories and discourses have been (literally) mobilized to nearly every part of the planet. Resonating with this particular flow, queer theoretical approaches have themselves called for a fluid set of identities and a movement away from biological ascription and essential or innate forms of sexual orientation. While the use of identity categories (such as gay and lesbian) has been the subject of much critique in queer theory, the purpose of this analytic deconstruction has not been to eliminate these categories or identities altogether. Rather, it is to emphasize a critical engagement with their meaning and purpose. The objective of establishing identity in asylum and refugee cases is to ensure a putatively innate truth. But this also involves uncovering whether, and how, these categories of identity resonate outside of the global north. In forming an epistemic subject for sexual refugee status, sexuality assumes another, legal and definitive identity. Sexuality becomes anchored in the individual by practices of self-representation such as those exercised between attorneys and their clients. Sexuality in these cases, as for Foucault (1979), is made visible through mechanisms of regulation that are simultaneously couched in terms of liberation (freedom from persecution in one's home country) and quasi-therapeutic acts of enunciating subjectivity. In these cases, sexuality is uttered in precise terminological forms and articulated to a juridical ear. If sexuality is, in some ways, sutured in place through these practices, it is also understood - by virtue of being embodied in a refugee subject - to be in motion and transpositioned. 


\section{Sexual migrations and transpositioned queer narratives}

Just as the identities of sexual migrants are impacted by structural conditions, cultural dynamics and institutions, so too are im/migration and sexuality mutually related; each of them are a series of practices and desires that overlap in experience and language. ${ }^{3}$ The ways in which sexual discourse shapes, contextualizes and conditions the dynamics of migration is a critical aspect of how migrants become incorporated into communities in places such as Canada and the United States (Cantú 2009, Cruz-Malavé \& Manalansan 2002, Hondagneu-Sotelo 2007, Luibhéid 2002). The interventions and analyses presented by the papers in this special issue consider sexuality across borders and across legal domains; in many cases they suggest that we move beyond an enduring focus in migration studies [End Page 141] that has centered on "sending" and "receiving" countries. Instead they draw attention to how sexuality becomes manifest in the discursive enterprises of migration law, articulations of asylum and queer settlement practices. The fact that sexual migration is situated within legal systems and structured by state processes cannot be ignored. There has been a significant gap, for instance, between Canadian provisions for queer immigration and those of the United States. Canada, which has instituted some of the most progressive LGBTQ immigration laws in the world, has long allowed Canadian citizens to sponsor their same-sex spouse, common-law partner or conjugal partner for immigration purposes. ${ }^{4}$ With the Supreme Court's overturning of the Defense of Marriage Act in 2013, the United States has only recently allowed for same-sex immigration rights. ${ }^{5}$ In other words, some borders have been more easily crossed than others. The authoritative force of the border, and histories of immigration from the global south to the global north each fortify exclusions and allow certain passages. Borders are inherently committed to a prohibitionary logic. But they are also, ironically, defined by the transport and flow of goods, people and finance. Borders are also often fraught and dangerous places, or what Gloria Anzaldúa (1987) called an "open wound." While all immigration laws render a series of policies that determine who will, and who will not, enter a country, LGBTQ im/migrants and potential sexual migrants have been victims of serialized discrimination, historically codified through policies of exclusion.

Regular immigration to the United States - as distinct from asylum or refugee processes - is predicated on the plenary power doctrine that nation states have the power and the right to control whether and how non-citizens enter state territory. In practice this has meant that certain kinds of immigrants are privileged over others according to the historical conditions and preferences of the time. Exclusions based upon sexuality did not begin with LGBTQ persons; they were, rather, part of a longer trajectory of racial, gender and sexual prohibitions in immigration law. The 1875 Page Law in the U.S., for instance, prohibited the entry of all Asian women who were believed to be immigrating to the country for "lewd or immoral" reasons. Chinese women incurred particular scrutiny during this period because they were suspected of coming to the U.S. in order to provide sexual services for male Chinese laborers. The Page Law, while specific in its mandates, also provided an ideological framework for other exclusions based on sexual deviance. The targeted exclusion of lesbians and gay men can be charted back to the period of the first World War. In 1917 persons deemed to have "constitutional psychopathic inferiors" were barred from entering the U.S. This category included a whole raft of persons thought to deviate from the norm including "moral imbeciles, pathological liars, swindlers, defective delinquents, vagrants and cranks" (Loue 1990: 129). This broad, highly interpretive categorization also [End Page 141] included, "persons with abnormal sexual instincts." A vast 
range of qualities that were considered non-normative became included in this nefariously flexible legal provision. Alejandra Velas is a case in point. Velas, who sought to enter the United States through Ellis Island in the 1910s, was described in the following way by the immigration authority who oversaw her application. At her time of entry, Velas was dressed in men's clothes. However, "she proved to be," the immigration authority wrote, "upon examination, despite her earlier insistence to the contrary, a young woman. [When a medical doctor questioned her] about why she wore men's clothes, she answered that she would rather kill herself than wear women's clothes" (Corsi 1969: 81). Velas was denied entry on the grounds of cross-dressing, a practice that fell within the scope of psychopathic inferiority.

Through the middle of the 20th century U.S. immigration policy systematically excluded LGBTQ individuals and other sexually suspicious subjects through the use of pathologizing terminology and categories. In this sense, immigration policy reflected a series of social shifts in Euroamerican culture that transformed "the sodomite" into "the homosexual" (Foucault 1979). Homosexuality had come to be understood, over time, as an immutable quality of being; or following Michel Foucault (1979), a "species." Someone could be dubbed a homosexual if they engaged in homosexual acts or had homosexual desires and, according to the logic of the time, this was best determined through the science of psychiatry, particularly the discursive instruments of psychopathology (Canaday 2009: 215). An already exclusionary ethos toward LGBTQ or other sexual im/migrants was reinforced in 1952 with the McCarran-Walter Act that banned all "psychopathic personalities" from entering the United States. The Public Health Service had concluded that "aliens afflicted with psychopathic personality [includes] homosexuals or sex perverts" (82nd Congress 1952: 9). Legal records from the 1950s and 1960s show that the same grounds were used to exclude the legal immigration of lesbians and gay men, or those thought to harbor same-sex attraction. In 1965, further revisions were made to immigration law, and the banning of gay men and lesbians was specifically codified under the claim that they were "sexual deviates." What each of these provisions illustrates is the way in which borders have been policed under the logic of sexual difference.

LGBTQ people, more so than their straight counterparts, have been subjected to the institutionalization of medico-sexual language and provisions that have, at times, prohibited their legal immigration to countries such as the United States. This is one reason why individual stories of LGBTQ immigration exclusion are difficult to enumerate. Many, if not most, of them are lost to history. Restrictions against the legal migration of LGBTQ people may have encouraged more covert, undocumented entry into certain countries, but this is very difficult to determine. What immigration laws clearly indicate, however, is that borders have been fraught [End Page 142] spaces where the twin anxieties of sexuality and transgression meet. In many ways, these border tensions tell us much more about legal and psychotherapeutic ideologies and discursive strategies of exclusion than they do about the lives of LGBTQ im/migrants. These histories of prohibition, it is worth pointing out, have endured for some time. It was not until 1990 that the ban on lesbian and gay immigrants to the United States was lifted and only in 2013 has it become possible to sponsor a same-sex partner for immigration purposes. For most of the 20th century immigration law barred lesbians and gay men from legally entering the United States. Ironically, however, the history of homosexuality is also a history of migration. 


\section{Queer histories of translocation}

The construction of modern gay identity (D’Emilio 1993 [1983]) was fundamentally shaped by the twin forces of capitalist development and the internal migration of gays and lesbians to urban centers. After World War II, military demobilization and new employment opportunities in the U.S. drew tens of thousands of lesbians and gay men to cities such as San Francisco, Los Angeles, Chicago and New York. These "great gay migrations" (Weston 1998: 41) resulted in the creation of urban communities where sexual identities became formed, often in stark contrast to the rural origins from which many gay men and lesbians had come. Rural-to-urban migration facilitated the formation of quasi-ethnic gay communities or "gay ghettos." Similar dynamics occurred in other countries in Latin America, Europe and Canada (Bunzl 2004, Thayer 1997). These queer enclave communities also generated an economic niche for what Gayle Rubin (1992 [1984]) has called the "gay economy". The economic "pull" of an independent, urban life and the persuasive "pull" to fulfill one's sexual self became merged through the act of internal migration. The booming post-war economy in the United States increasingly allowed individuals to support themselves through wage labor, independent from their families of origin. Ultimately, economic factors and urban clusters of "erotic minorities" (Rubin 1992 [1984]) became the basis for a burgeoning sense of individual sexual identity, one that would grow and thrive outside the confines of heterosexual normativity. Gay and lesbian identity has been profoundly influenced by migration, both internationally and within the bounds of the nation state.

To use the idioms of migration scholars and policy makers, social conditions both "pushed" and "pulled" lesbian and gay migrants to U.S. cities in the mid $20^{\text {th }}$ century. However, scholarship explicitly accounting for sexuality and subjectivity within processes of migration is a relatively new approach. "Sexual migration" (Cantú 2009, Parker 1997) — im/migration that is motivated, entirely or in part, by the sexuality of the person migrating - is a concept that begins to account [End Page 143] for the multiple, overlapping experiential dimensions of migration and sexuality. Sexual migration, as all of the papers in this special issue have found, involves multiple moments of meeting and transposition: encountering the self and encountering new social worlds, often through linguistic practices. Sexual migration is not simply located in the mind (or heart) of the person engaged in migration; rather it is rooted in a range of experiences, including the perceived or actual conditions in the receiving country, migrants' experiences en route, and the social, economic and legal conditions in the sending country. Sexual migration may be predicated on multiple factors including pursuing a romantic relationship with a foreign partner, seeking new self-definitions of sexual identity or fulfilling sexual desire. It may be an avenue to escape discrimination or persecution based on sexual difference, or it may be founded on a search for greater sexual equality and rights (Carrillo 2002, 2004).

The concept of sexual migration is one that is indebted to prior research on migration, especially that which has argued that immigration is not "an event" but rather "a process" that is conditioned by race, gender and class dynamics (Hondagneu-Sotelo 2007, Pedraza 1991, Portes $\&$ Rumbaut 1996). However, the political economic frameworks that inform many studies of migration have, for the most part, presumed that migrants are heterosexual. This supposition, in turn, has influenced the ways that scholars view the role of migrant families and the networks that they often provide. More conventional, neoclassical approaches to migration have emphasized that migrants are individual, autonomous actors who make rational, calculated decisions following a kind of cost-benefit analysis. These perspectives on im/migration, perhaps unsurprisingly, have generally ignored sexuality as an important motive in migration whether as 
a "pull" or a "push" factor; nor have they allowed for the shifting discourses and sensibilities of the self that inform these processes. The concept of sexual migration, conversely, encourages us to consider the intersections that condition im/migration, including systems of citizenship, national identity and the role of race in these dynamics (Alexander 1994, Espín 1999, SánchezEppler \& Patton 2000). To more fully comprehend the myriad dynamics of sexual migration, however, it is important to look at the ways in which language and discourse operate to condition both institutional structures as well as individual and collective subjectivity.

As we see in Hinda Seif's article, new alliances between queer youth and undocumented immigrants demonstrate how the relationship between sexual identity, undocumented status and linguistic strategies to be "out" are intimately related phenomena. Seif describes that the " 1.5 generation" is a subjective force to be reckoned with. As undocumented immigrants who arrived in the United States before they were age 15 (and under the age of 31 in June 2012), this strata of immigrants, many of whom were brought by their parents from Mexico and Central America, [End Page 144] became eligible for President Obama's "Deferred Action for Childhood Arrivals" (DACA) Program. However, preceding the president's decree, undocumented youth were already actively involved in producing campaigns to "come out of the shadows" (Seif 2011). Many of the youth in leadership positions in these struggles identify as queer and are very publically out and visible: pronouncing both their undocumented and queer subjectivity through iterative practices of coming out in both registers. Seif's discussion follows the innovative political organizing techniques and linguistic strategies utilized by these movements, and argues that the mobilizations that they were able to achieve have had a profound impact and influence on U.S. immigration policy. As Seif recognizes, in both her methodological approach and in her analysis, these campaigns for visibility and emergence from the "shadows" have been taking place in the mediated domains of Facebook and YouTube. While queer and undocumented youth utilize the social media tools associated with their generation to enhance and expand their activism and linguistic repertoire, there are also generational distinctions among undocumented migrants that impact the dynamics of revelation and coming out.

Adult migrants who have entered the United States without documentation often speak about their papeles chuecos (crooked papers), indexing the falsified documents that they have had to obtain in order to bureaucratically navigate life in the U.S. The children of these $\mathrm{im} /$ migrants, coming of age in the U.S., experience similar difficulties related to their utilization of precarious papers. Without a social security number, for instance, they are prevented from enrolling in all of the privileges and markers of adulthood - college applications, financial aid forms, driver's license applications and so on. While the challenges of lacking or "crooked" papers impacts both generations, the act of coming out as undocumented has very different potential consequences. Youth coming out as undocumented may expose the undocumented status of the entire family. There is risk involved, especially given that older family members may be responsible for the original illegal crossing into the United States. The particular experiences of undocumented queer youth, especially those that come out in both dimensions, illustrates important correspondences between the discursive practices of coming out as undocumented and coming out as queer. As youth themselves describe, their sense of sexuality is a very specific, individual, pleasurable and intimate domain. Coming out of the shadows as undocumented, conversely, is a public enunciation that may endanger their relationships with parents and other family members. Thus, while coming out as undocumented and queer entails similar practices of revelation, the stakes are quite distinct as are the ways in which they are felt and enunciated. As Seif shows us through her conversations with youth, being undocumented is 
bureaucratically based while sexuality is deeply sentimentalized as an inherent aspect of one's true self. In this sense, the undocumented youth we encounter in [End Page 145] Seif's ethnographic and linguistic portraits share the essentialized sexuality that is intrinsic to the legal discourses where sexuality is categorized as an "immutable" characteristic. In their complex and rapidly shifting subjectivities, queer youth coming out with their sexuality and coming out of the shadows, demonstrate the multiple ways that identity is evoked and affectively engaged. Their stories, importantly, remind us that the qualities of sexual subjectivity and the kinds of sexual migrations that people make are multiple; while it may involve crossing international borders, there may be other intersubjective life transpositions that are more significant.

The semantics of subjectivity meet the material realities of income, ethnic ascription and the power of location in María Viteri's contribution to this special issue. Viteri's discussion of the immigrant Ecuadorian LGBT community in New York City coalesces many of the contingencies of queer migration to the United States. Viteri contextualizes her study within the ongoing global economic crisis and focuses attention on how questions of labor, employment opportunities and networks impact the possibilities for Ecuadorian gay male immigrants. She is attentive to how these communities exercise specific forms of social reproduction and language use, as they contend with processes of exclusion, including deportation and xenophobia. Viteri's article follows in the footsteps of Lionel Cantú's pioneering work on sexuality and migration as she describes her methodology as a "queer anthropological approach." This, she describes, involves a Deleuzian deterritorialization and rhizomatic articulation of migration that does not assume a fixed point of departure and arrival. Thus her aim is to find the articulations between sexuality discourses and narratives of migration, not by resorting to demographic metrics but rather by focusing on how power relations condition both the migration journey and affect those who remain at home.

Without discounting the fact that countries such as Canada, the United States and many European countries may offer many opportunities to LGBTQ migrants in terms of employment and sexual tolerance, it is also important to remember that migration to these places is not always or necessarily a move from repression to unqualified liberation; these are not simple stories of assimilation and tolerance. Analyzing the discourses surrounding the murder of an Ecuadorian man in New York City, Viteri shares a report from The New York Times that surfaces the interrelationship between violence and discrimination. "Prosecutors say the men assaulted the brothers because they were Hispanic and because the suspects mistakenly believed that the brothers were gay." Queer and Latino operate as parallel diagnostic categories in the explication of violence. The confounding, or perhaps better said, the co-founding, relationship between a murder based on (perceived) race or because of (perceived) sexual identity shows us that as much as "intersectionality" may be overdetermined in the academic universe of gender and sexuality studies, [End Page 146] it continues to operate on the street and in courtrooms as motive and fault must be found.

Discursive practices of transnational sexual selfhood, as we see in Ahmed Afzal's article, are an integral aspect of sexual migration practices. In his examination of gay South Asian Muslim American men in Houston, Texas, Afzal locates several dynamics and discourses that his interlocutors use to establish their identities in multiple registers. Afzal argues that the construction of sexual subjectivity is far less tethered to interactions with state officials than it is to ideals constructed through a tripartite set of discourses and practices. Gay South Asian Muslim American men, he finds, are committed to reinvoking patterns of homosociality associated with their natal country, as well as strategically using homonormative scripts that 
predominate in the United States. However, what sutures these "traditional" and "transnational" reappropriations of sexual subjectivity is the equally important commitment of these men to a transnational Muslim ummah. For instance, we read about how Shahrukh was better able to resolve his sense of having failed his mother by resituating his homosexuality as intrinsic to his identity; this in turn allowed him to establish his life independently as a gay male. As Afzal argues, it is through appropriating homonormative western models of sexuality and accompanying linguistic strategies that these men are able to create transnational identities in the United States. Continuing to be a part of a larger Muslim world, both online (through the AlFatiha Organization for example) and in and around Houston, is foundational to South Asian gay men's sense of self. Each of these exercises to create and maintain identity in contexts that are shifting, sometimes unfamiliar, and at times hostile to both queer men and Muslims, demonstrate how Afzal's interlocutors are actively engaged in establishing a supportive sense of camaraderie between and among themselves. Their interactions and values the ways in which the Ecuadorian men in Viteri's study create community. They draw upon the legitimated linguistic and social spaces of gay identity in the U.S. without losing sight of their own histories, languages and heritage. Like the "global divas" that Martin Manalansan encountered in New York City, the multiple and shared experiences of religion, sexuality and a sense of home work to cohere and reproduce the possibilities of transnational sexual identity.

Gay South Asian men in Houston maintain links, both personal and religious, to their homelands and, at the same time, draw from repertoires of gay liberation and individuality that characterize much of the cultural discourse in the United States. They are also actively transpositioning a very specific form of identity that blurs the distinctions between "platonic" and "sexual" relationships (Afzal 2005). The men with whom Afzal works describe that they are seeking a yaar — an individual with whom one feels a deep, almost intangible connection, someone who is both a friend and a lover. The category of yaar follows from a South Asian cultural [End Page 147] script for male friendships that are not contoured to heteronormativity, but neither do they replicate a western model of globalized "gay" subjectivity (Altman 2002). Among both Indian American men and Pakistani American men, Afzal finds the conceptual rubric of yaari to be central to their reckoning of romantic relationships with other men. The men in Afzal's study are, as we see, defining forms of male homoerotic activity that are profoundly situated within relationships of friendship and reciprocal shared interests. Yaari embodies ideals of companionate relationships: both best friends and compatible sexual partners. While the men in Afzal's study identify as "gay" in a transnational register, their affective commitment is to a very specific, localized and historically situated form of relationality and identity that is not solely predicated on sexual practices. This form of sexual migration, where the conceptual values of yaari are imported and re-worked in the context of the United States, is a clear example of how sexual ideoscapes travel. Moreover, it illustrates how "receiving" countries are themselves transformed by the rich repertoires of sexual difference that are embodied in transnational queer identities and language practices.

\section{Language, sexual asylum and the social visibility test}

As the history of immigration has demonstrated, the great majority of policies have operated to protect the sovereignty of the nation-state and its borders. However, asylum and refugee immigration has been informed by a very different legal logic (Luibhéid 2005: xvi). Asylum and 
refugee provisions are structured by human rights paradigms and a commitment to upholding international human rights laws. They have been instituted in order to provide sanctuary and refuge for people being persecuted in their home countries because of their race, nationality, religion or political opinion. ${ }^{6}$ In many countries around the world, asylum and refugee status can also be provided to those who have, as the legal discourse puts it, a "well-founded fear" of persecution because of their "membership in a particular social group." It was through this provision that, in 1986, "sexual" asylum in the United States was made possible. The first move toward legitimating LGBTQ persons as potential candidates for asylum came when a Houstonbased immigration judge ruled that the Immigration and Naturalization Service could not deport a Cuban gay man, Fidel Armando Toboso-Alfonso, because he would face persecution due to his sexual orientation if he were returned to Cuba. In 1990, the Immigration and Naturalization Service appealed the Toboso-Alfonso case, but the Appeals board upheld that gays were a "particular social group" deserving asylum. In 1993 an immigration judge in San Francisco granted asylum to a Brazilian man and in 1994, the INS, for the first time, granted asylum directly [End Page 148] to a Mexican gay man. Later that year Attorney General Janet Reno elevated the Toboso-Alfonso case to the status of precedent, fully establishing that homosexuals (male or female) constituted a legitimate class of persons who could seek political asylum in the United States. The possibility of sexual asylum in the United States, especially given the history of immigration law, constitutes a dramatic shift for LGBTQ migrants, documented and undocumented. $^{7}$

Each of the legal steps toward creating a space for sexual refugees has not been without controversy and sexual asylum continues to be difficult to obtain. In the early years of U.S. sexual asylum provisions, between 1994 and 1997, of the over 1,000 petitions that were filed by LGBTQ applicants only sixty were granted. In 2011, of the total 36,000 asylum claims that were approved in U.S. courts, 102 of them went to LGBTQ people seeking refuge from antigay persecution (Brydum 2012). According to Rehaag (2008: 71), approximately half of the 1351 petitions based on sexual orientation that were filed in Canada were accepted prior to 2004 . In the United States since the 1990s the courts have issued different, and sometimes contradictory, rulings on asylum seeking by same-sex attracted persons. Cases are difficult to win, and require extensive legal advice and many hours of legal labor. The costs associated with the process in the United States, as well as the initial knowledge required to seek out and secure such assistance, means that the asylum system overall continues to be most accessible to those who are male, heterosexual and economically privileged. ${ }^{8}$ To successfully achieve sexual asylum, an applicant must establish, convincingly, that she or he is, in the first instance a "member of a particular social group." In the second instance, the applicant must prove that membership in that group has been the source of past persecution, or will be the basis of future acts of violence against them.

For some LGBTQ migrants sexual asylum can offer a means of escape from persecution in one's home country. It is for some, literally, life saving. It is also an indication of how far immigration laws have come since the days of banning lesbians and gays as "sexual deviates." While U.S. law has generally been conservative about extending rights to LGBT persons, immigration courts addressing asylum claims have recognized LGBT status as a basis for asylum (Southam 2011). However, it is also important to point out that sexual asylum is politically and ideologically structured in particular ways. The Matter of Acosta established the general framework in the U.S. for what constitutes membership in a particular social group. Specifically it is those who share a "common immutable characteristic" that is either "innate" or "arises from 
past experience" (Cantú, Luibhéid \& Stern 2005: 64). Successful asylum claims, therefore, require that the applicant prove that his or her being gay is an "immutable" characteristic; sexuality must be, in other words, a quality that is certifiably unchangeable. As researchers have found in Canada and other countries "a claim to belong to a particular social group on [End Page 149] the basis of sexual orientation depends upon the presentation of a very internal form of self identity" (Berg \& Millbank 2009: 196). This stance dovetails well with the argument that being gay or lesbian is not a "choice" or a "lifestyle" but rather, a predetermined and innate quality. However, from the point of view of queer theorists and others, sexuality as preprogrammed and essentialized in the ways that the immutability argument demands is problematic because it forecloses a more flexible and fluid definition of sexuality. The "cause" of homosexuality in this context is a sexual ontology that subscribes to a durable and fixed manifestation of the sexual self.

In addition to their "inherent" homosexuality, asylum claimants must also prove that they would invariably face persecution or violence if they were returned to their country of origin. Applicants and their attorneys are required to carefully detail how the applicant's home country is unsafe and intolerant of sexual minorities; this entails accounting for multiple social dimensions and experiences, from family life to judicial systems. Providing a portrait of the "country conditions," often through expert testimony, is a critical aspect of an individual's asylum claim, allowing the judge or Review Board to determine whether or not there is a clear and present danger of violence for the claimant. This legal requirement stresses that the country of origin be demonstrably intolerant. In the cases we have read about in this special issue, the United States or Canada must be rhetorically constructed as places of unimpeachable liberty, progressive havens of sexual sanctuary. Through these kinds of logics, the country of origin must be the inverse of the asylum destination: the former must appear to be thoroughly entrenched in putatively retrograde cultural practices while the latter is a site of sexual refuge. These sorts of arguments invariably involve some degree of cultural stereotyping that render sending countries as "backward" or "un-modern." The important question in an epistemological sense is not whether any one country is patently more repressive toward sexual minorities than another. Rather it is to recognize that sexual asylum is a legal process that may, if unintentionally, reinforce old colonial scripts of third world "backwardness" and first world "modernity." It is an imperfect legal apparatus, but nevertheless, an important one for queer im/migrants; it is also a process that is mediated by many layers of legal intervention, petitions and expert testimony.

The asylum applicants with whom Nathalie Ricard works are beholden to expert assessments and juridical provisions. However, throughout her article we also see how applicants linguistically negotiate the affective dimensions of sexual migration and queer transpositions. Ricard describes the cartographic qualities of queer asylum, as well as the process of metaphorizing one's experience into terms commensurate with legal constructs that qualify one as "gay enough." Ricard draws our attention to many of the affective dimensions of asylum seeking. As [End Page 150] Deborah Gould (2009: 20) has described it, affect is, "the body's ongoing and relatively amorphous inventory-taking of coming into contact and interacting with the world [...]. Affect is unbound: it has no fixed object, no prior aim; rather it is unattached, free-floating mobile energy." In Ricard's vivid re-telling of Daniel's story we find striking affective resonance. He says, "When I think about the ship, I feel sick. I drank seawater and ate biscuits for weeks. I didn't know day and night." This sense of disorientation, embodied malaise, confusion about where one is, or even whether it is day or night, seems an apt metaphor for many of the stories we have read in this special issue. There is, on the one hand, the importance of 
coming to know one's sexual self, and the ability to explain that self, all the while knowing that this self exists in and alongside a series of confusions and unfamiliarity. Some of the heroic work that asylum seekers and other queer migrants do is to affectively reconcile these competing sentiments and lived realities. They take on a further border crossing responsibility, or queer transposition, as they are encouraged to resolve their own complex histories into a codifiable sexual self (Ricard 2011).

One element that repeatedly arises in asylum cases is that rarely is it solely sexual persecution that claimants have faced. More often, they have survived multiple kinds of injustice and inopportunity, from poverty to racism, from violence to abuse. Daniel for one, faced many, many barriers before he was able to arrive in North America and discover the possibility of asylum; it seems almost miraculous that he was able to obtain it. As Ricard explains, Daniel was left on the street as a baby. He was unable to complete an even minimal education, nor was he aware that persecution based on one's sexual orientation could be the basis for an asylum claim. Daniel's ability to become a sexual subject, and to pursue asylum, is conditioned by multiple other elements of his marginalization. His case reminds us of all those sexual subjects who are not represented here: those who were never directed to the possibility of asylum and those who were not fortunate enough to have the networks or economic resources required to achieve sexual asylum.

\section{Conclusion: Juridicosexual expertise and the language of the law}

Passing the "social visibility test" has been a mandatory exercise for those hoping to achieve sexual asylum in the global north. In these settings, it is paramount that claimants establish and adhere to an inherent, predetermined and immutable orientation and identity. However, of course, sexual identity can and does have many distinct manifestations. It can serve as a powerful indicator of subjectivity and a way to create networks and alliances. It can operate on a more ephemeral register, eluding a precise definition, or it may work to determine one's "immorality" or "suspect" subjectivity. As we see in the discussions that treat the complexities of [End Page 151] sexual migration there are a wide range of practices and experiences that constitute sexual migration. But in the world of legal protocols, diversity tends to become distilled and codified as an unimpeachable truth. Within the context of migration and asylum, LGBTQ-ness ought to serve as an approximation and a marker more than a definitive description of behaviors, sentiments or lived experience (Boellstorff 2007, Kulick 2000), but this is often more difficult in practice than in theory. In the discussions featured in this special issue, we see that a series of legal proddings and terminological maneuvers make individuals into sexual beings that are recognizable and legible to the juridical eye. We also see how asylum seekers, their attorneys, IRB members, expert witnesses and the idiom of law itself determine who counts as a truly persecuted entity. Expert interventions and the bodies and lives around which they are uttered repeat narratives of sexual subjectivity that, in many ways, tell us less about the subject and his or her discursive practices than about the juridical apparatus and the apertures of state citizenship that define them. Each of the authors in this special issue have found ways to achieve a deeper understanding of sexual adjudications and the linguistic strategies used to create or subvert them. And in this sense, they have brought us into more intimate contact with the terminological transpositions of queerness across borders and within them. 


\section{Notes}

1. See http://seattletimes.com/html/localnews/2008597807_immigration07m0.html (accessed 15 January 2013).

2. See http://www.nytimes.com/2011/01/29/nyregion/29asylum.html?pagewanted=all\&_r=0 (accessed 15 January 2013).

3. The intersection of sexuality and migration is not only pertinent to LGBTQ migrants, but nonqueer migrants as well (González-López 2005). As Gloria González-López (2005: 251) has suggested, "heteronormative models of sexuality are [also] fluid and vulnerable to forces such as migration."

4. For current information on Canadian immigration, asylum and refugee legislation and criteria see the website of the non-profit organization LEGIT (Canadian Immigration for Same-Sex Partners) available at: http://www.legit.ca (accessed 20 January 2013).

5. For further information see U.S. Citizenship and Immigration Services: http://www.uscis. gov/portal/site/uscis/menuitem.eb1d4c2a3e5b9ac89243c6a7543f6d1a/?vgnextoid=2543215c31 0af310VgnVCM100000082ca60aRCRD\&vgnextchannel=2543215c310af310VgnVCM1000000 82ca60aRCRD and Immigration Equality: http://immigrationequality.org/issues/couplesandfamilies/faqs-for-binational-couples/ (accessed 23 August 2013).

6. Refugee and asylum provisions in U.S. law were developed after the Second World War and codified in 1951 in the Convention on the Status of Refugees.

7. Asylum has also been an important mechanism for undocumented LGBTQ migrants because it has been one of the few ways that one can acquire legal standing from inside the United States (Soloman 2005).

8. In Canada, asylum seekers are able to apply for legal aid, meaning that the process is less financially onerous.

\section{References}

82nd Congress. 1952. Revision of Immigration and Nationality Laws. S. Rep. 1137.

Afzal, Ahmed. 2005. Family planning and male friendships: Saathi condom and male same sexsexual desire in Pakistan. In Culture \& the Condom, Karen Anijar \& Thuy Dao Jensen (eds), 177-205. New York: Peter Lang.

Alexander, M. Jacqui. 1994. Not just (any) body can be a citizen: The politics of law, sexuality and postcoloniality in Trinidad and Tobago and the Bahamas. Feminist Review 48: 5-23. DOI: $10.1057 /$ fr. 1994.39

Altman, Dennis. 2002. Global Sex. Chicago: University of Chicago Press.

Anzaldúa, Gloria. 1987. Borderlands/La Frontera: The New Mestiza. San Francisco: Spinster/ Aunt Lute Press. 
Berg, Laurie \& Millbank, Jenni. 2009. Constructing the personal narratives of lesbian, gay and bisexual asylum claimants. Journal of Refugee Studies 22(2): 195-223. DOI: 10.1093/jrs/ fep010

Boellstorff, Tom. 2003. Dubbing culture: Indonesian gay and lesbi subjectivities and ethnography in an already globalized world. American Ethnologist 30(2): 225-242. DOI: 10.1525/ae.2003.30.2.225

Boellstorff, Tom. 2007. Queer studies in the house of anthropology. Annual Review of Anthropology 36: 17-35. DOI: 10.1146/annurev.anthro.36.081406.094421

Brydum, Sunnivie. 2012. LGBT asylum seekers win life in U.S. after persecution abroad. The Advocate, November 21, 2012. <http://www.advocate.com/news/worldnews/2012/11/21/persecuted-lgbts-find-asylum-us> (accessed December 19, 2012)

Bunzl, Matti. 2004. Symptoms of Modernity: Jews and Queers in Late-Twentieth-Century Vienna. Berkeley: University of California Press.

Butler, Judith. 2004. Undoing Gender. New York: Routledge

Canaday, Margot. 2009. The Straight State: Sexuality and Citizenship in Twentieth-Century America. Princeton: Princeton University Press.

Cantú, Lionel. 2009. The Sexuality of Migration: Border Crossings and Mexican Men Immigrant Men. New York: New York University Press.

Cantú, Lionel, Luibhéid, Eithne \& Stern, Alexandra Minna. 2005. Well founded fear: political asylum and the boundaries of sexual identity in the U.S.-borderlands. In Queer Migrations: Sexuality U.S. Citizenship and Border Crossings, Lionel Cantú \& Eithne Luibhéid (eds), 61-74. Minneapolis: University of Minnesota Press.

Carrillo, Hector. 2002. The Night is Young: Sexuality in Mexico in the Time of AIDS. Chicago: University of Chicago Press.

Carrillo, Hector. 2004. Sexual migration, cross-cultural sexual encounters, and sexual health. Sexuality Research \& Social Policy: Journal of the NSRC 1(3): 58-70. DOI: 10.1525/ srsp.2004.1.3.58

Corsi, Edward. 1969. In the Shadow of Liberty. New York: Arno Press.

Cruz- Malavé, Arnaldo \& Manalansan, Martin F. 2002. Queer Globalizations: Citizenship and the Afterlife of Colonialism. New York: New York University Press.

D’Emilio, John. 1993 [1983]. Sexual Politics, Sexual Communities: The Making of a Homosexual Minority in the United States, 1940-1970. Chicago: University of Chicago Press.

Espín, Olivia M. 1999. Women Crossing Boundaries: A Psychology of Immigration and Transformations of Sexuality. New York: Routledge.

Foucault, Michel. 1979. The History of Sexuality: Volume I. New York: Pantheon Books.

González-López, Gloria. 2005. Erotic Journeys: Mexican Immigrants and their Sex Lives. Berkeley: University of California Press.

Gopinath, Gayatri. 2005. Impossible Desires: Queer Diasporas and South Asian Public Cultures. Durham: Duke University Press. DOI: 10.1215/9780822386537

Gould, Deborah B. 2009. Moving Politics: Emotion and ACT UPs Fight against AIDS. Chicago: University of Chicago Press. DOI: 10.7208/chicago/9780226305318.001.0001

Hondagneu-Sotelo, Pierrette. 2007. Doméstica: Immigrant Workers Cleaning and Caring in the Shadow of Affluence. Berkeley: University of California Press.

Howe, Cymene. 2009. The legible lesbian: Crimes of passion in Nicaragua. Ethnos 74(3): 361378. DOI: 10.1080/00141840903053121 
Howe, Cymene. 2013. Intimate Activism: The Struggle for Sexual Rights in Postrevolutionary Nicaragua. Durham: Duke University Press. DOI: 10.1215/9780822378969

Kulick, Don. 2000. Gay and lesbian language. Annual Review of Anthropology 29: 243-285.

Leap, William L. \& Boellstorff, Tom (eds). 2003. Speaking in Queer Tongues: Globalization and Gay Language. Urbana: University of Illinois Press.

Loue, Sana. 1990. Homosexuality and immigration law: A re-examination. Journal of Psychiatry and Law 18(1/2): 109-136.

Luibhéid, Eithne. 2002. Entry Denied: Controlling Sexuality at the Border. Minneapolis: University of Minnesota Press.

Luibhéid, Eithne. 2005. Introduction: Queering migration and citizenship. In Queer Migrations: Sexuality, U.S. Citizenship and Border Crossings, Lionel Cantú \& Eithne Luibhéid (eds), ix-2. Minneapolis: University of Minnesota Press.

Malkki, Liisa. 1995. Refugees and exile: From refugee studies to the national order of things. Annual Review of Anthropology 24: 495-523. DOI:

10.1146/annurev.an.24.100195.002431

Manalansan, Martin F. 2003. Global Divas: Filipino Men in the Diaspora. Durham, NC: Duke University Press. DOI: 10.1215/9780822385172

Murray, David A.B. 2012. Becoming queer here: Learning to be a sexual minority refugee in Toronto. Refuge: Canadas Journal on Refugees 28(2): 127-135.

Parker, Richard. 1997. Migration, sexual subcultures, and HIV/AIDS in Brazil. In Sexual Cultures and Migration in the Era of AIDS, G. Herdt (ed), 55-69. Oxford: Clarendon Press.

Pedraza, Silvia. 1991. Women and migration: The social consequences of gender. Annual Review of Sociology 17: 303-325. DOI: 10.1146/annurev.so.17.080191.001511

Portes, Alejandro \& Rumbaut, Ruben G. 1996. Immigrant America: A Portrait. Berkeley: University of California Press.

Povinelli, Elizabeth A. 2004. The Cunning of Recognition. Durham: Duke University Press.

Rehaag, Sean. 2008. Patrolling the borders of sexual orientation: Bisexual refugee claimants in Canada. McGill Law Journal 53(1): 59-102.

Ricard, Nathalie. 2011. Le prix à payer pour devenir sujet de droit: La sélection des réfugiés allosexuels au Canada ("The price to pay to become a legal person: The selection of queer refugees in Canada"). Alterstice - Revue Internationale de la Recherche Interculturelle 1(2): 79-96.

Rubin, Gayle. 1992 [1984]. Thinking sex: Notes for a radical theory of the politics of sexuality. In The Gay and Lesbian Studies Reader, Henry Abelove, Michéle Aina Barale \& David M. Halperin (eds), 3-44.. New York: Routledge.

Sánchez-Eppler, Benigno \& Patton, Cindy (eds). 2000. Queer Diasporas. Durham: Duke University Press.

Sedgwick, Eve Kosofsky. 1990. Epistemology of the Closet. Berkeley: University of California Press.

Seif, Hinda. 2011. Unapologetic and unafraid: Immigrant youth come out from the shadows. New Directions for Child and Adolescent Development 134: 59-75. DOI: 10.1002/cd.311

Soloman, Alisa. 2005. Trans/Migrant: Christina Madrazos all-American story. In Queer Migrations: Sexuality, U.S. Citizenship and Border Crossings, Lionel Cantú \& Eithne Luibhéid (eds), 3-29. Minneapolis: University of Minnesota Press. 
Southam, Keith. 2011. Who am I and who do you want me to be? Effectively defining a lesbian, gay, bisexual, and transgender social group in asylum application. Chicago-Kent Law Review 86: 1363-1387.

Thayer, Millie. 1997. Identity, revolution and democracy: Lesbian movements in Central America. Social Problems 44(3): 386-407. DOI: 10.2307/3097184

Weston, Kath. 1998. Long Slow Burn: Sexuality and Social Science. New York: Routledge.

Author's address

Cymene Howe

Department of Anthropology

Center for the Study of Women, Gender \& Sexuality

Rice University

6100 Main St., MS 20

Houston, TX 77005-1827

United States

cymene@ rice.edu 